\title{
THE CHALLENGE FOR A HISTORICALLY DISADVANTAGED SOUTH AFRICAN UNIVERSITY TO PRODUCE MORE POSTGRADUATE STUDENTS
}

\author{
R. Sonn \\ Continuing and Adult Professional Teacher Development \\ Walter Sisulu University, Ibika Site \\ Butterworth, South Africa \\ e-mail: rsonn@wsu.ac.za
}

\section{ABSTRACT}

There is a shift in emphasis in higher education from producing bachelor's degrees en masse to an increase in the production of graduates with post-graduate qualifications. In recent times more and more universities in South Africa place emphasis in recruiting students doing post-graduate degrees and encourage them to complete their research component of their studies in the stipulated time in order to increase the subsidy received from the Department of Higher Education and Training (DHET) and the research output of students and staff. For Walter Sisulu University (WSU), this issue is relatively crucial, given its low throughput rate of post-graduate students. This article in particular draws from a research study conducted with BEd (Hons) and MEd students at WSU Ibika Site to establish the challenges they experienced in doing their research. The students usually finish their course work in record time, but find it very difficult to complete the research component of the programme. The result is that there are a number of students in the system. This qualitative study explored the challenges faced by these students in completing the research component of their respective programmes. A purposive sample of 20 students were selected to participate in the study. Interviews were conducted to collect the data. Ethical considerations were employed. Content analysis was used to analyse the data. Some of the challenges experienced by the participants included, inter alia, problems experienced in identifying the problem statement; the complexity of proposal writing; a lack of professional writing skills; etc. Based on the findings of the study the author provided some recommendations.

Keywords: resource-based economy, knowledge-based economy, post-graduate studies, problem statement, proposal writing, supervisor

\section{INTRODUCTION}

It has become a policy imperative in the South African context that the training of future researchers in Education should start at the Honours level. In this regard Thaver, Holtman and Julie $(2013,1136)$ remarks that within the global knowledge framework much emphasis is placed on the need for strengthening the number and range of doctorate or $\mathrm{PhD}$ holders which 
is perceived to stimulate the research capacities of economies. According to the National Development Plan (NDP 2013) the policy imperative in South Africa also stresses the need for further growth in the number of post-graduate students in order to ultimately produce more than 100 doctoral graduates per million per year by 2030. That implies an increase from 1420 in 2010 to well over 5000 a year (NPD 2013, 59). Academics and policy-makers recognise the necessity for South Africa to progress from a resource-based economy to a knowledge-based economy, as envisaged by the National Development Plan (NDP 2013, 59). That understanding has resulted in a shift in emphasis in higher education from producing bachelor's degrees en masse to an increase in the production of graduates with post-graduate qualifications (Thaver et al. 2013, 1138). However, grasping the necessity and bringing it to fruition are two different matters.

For South Africa to achieve better productivity and competitiveness, its tertiary educational institutions are required not only to supply the economy with appropriate scarce and critical skills, but also to contribute to research and development of new technology and with new organisational forms and innovation (DoE 2007). Recent national policy shifts also mean that higher education institutions are now required to align and coordinate their strategies with the state's reprioritisation of socio-economic development goals that favour the poor and socially marginalised (Phakiti 2008, 24). Many countries, both developed and developing, see the benefit of investing in their citizens.

Enabling graduates to obtain post-graduate qualifications is a way to create the link between the value of knowledge and national economic growth. South Africa is investing in this way and tertiary institutions should seek to increase their post-graduate intake (numbers). According to Campbell $(2003,901)$ South Africa is far from producing an adequate number of skilled professionals. A report produced by the Department of Higher Education and Training (DHET 2012) states that only 15 per cent of university undergraduate students' graduate, while the rate for master's graduates is about 20 per cent and for doctoral graduates about 12 per cent. The government recognises the shortfall. Higher Education and Training Minister Nzimande has said that growing knowledge economy is a key principle of his department's mandate (DHET 2012). He went further to explain that one of the challenges facing the country is the revitalisation of the academic profession, since the average age of a South African academic is 59 years. The minister is on record saying that universities should think about using retired academics to strengthen the capacity of the system in the areas of research and innovation.

The Department of Science and Technology has introduced what is called the national system of innovation under which it identified three main pillars: technology missions and 
science platforms; human capital development and knowledge production; and knowledge exploitation and innovation (DST 2013). Reiterating the goals set by the NDP the DHET (DHET 2012) states that PhD graduates, either as staff or post-doctoral fellows, should be the dominant drivers of knowledge production. That means that 75 per cent of university academic staff should hold PhDs, and institutions should produce more than $100 \mathrm{PhD}$ graduates per million of the population (DHET 2012).

Higher Education South Africa (HESA), an inter-university academic body, notes in its annual report (HESA 2013) that while the country's science and technology rankings as far as research output may match those of other middle-income developing economies, these achievements are under threat. The active researchers in the country are gradually ageing while not enough younger researchers and academics are being recruited and retained (HESA 2013). According to Quinn $(2012,72)$ combined age and race data suggest that a serious crisis is looming. As the over-50 largely white and male cohort moves closer to retirement, there is little evidence of commensurate black and female cohort waiting in the wings and ready to emerge.

\section{AN OVERVIEW OF THE SITUATION AT WALTER SISULU}

Given the historical legacy, there are significant transformation challenges facing WSU. It is common knowledge that WSU was never strong on its research output. In virtually all the research reports that were given in the past WSU was either last or second from the bottom as far as research output was concerned. The merger of the legacy institutions, (University of Transkei (UNITRA) with former Border Technikon and Eastern Cape Technikon) have not help matters. Research has shown that the two previous Technikons had no or very few programmes with a research component. The same could be said for UNITRA. During the nineties it was mostly academics in the Faculty of Science and Health Sciences that produced programmes with a research component. It is against this backdrop that an Honours-level qualification takes on significance insofar as it is the point at which students are introduced to an academic research sensibility. In other words, it is increasingly seen as the opportunity to induct students into an academic research culture.

According to the realignment of The Higher Education Qualifications Framework (HEQF) from 2012 onwards all Social Science Honours qualifications were compelled to have to include a compulsory 30 credit research module comprised of basic research and a research project. At WSU (Ibika Site) the Faculty of Education has introduced a research component in 2012 to its Bachelor of Education Honours (BEd (Hons)) degree in Educational Management and Policy. Students are expected to complete a research project with their course work. Of importance for 
the current article is that the research project constitutes 32 credits. In the past the students doing BEd (Hons) were only expected to complete their course work without the research project. As Table 1 will reveal students were relatively successful.

Table 1: Throughput rate of BEd (Hons) students since 2009

\begin{tabular}{|c|c|c|}
\hline Year & Number Enrolled & Number Graduated \\
\hline 2007 & 121 & - \\
\hline 2008 & 195 & 152 \\
\hline 2009 & 196 & 103 \\
\hline 2010 & 105 & 60 \\
\hline 2011 & 72 & 48 \\
\hline 2012 & 55 & 12 \\
\hline 2013 & 30 & 2 \\
\hline 2014 & 30 & 2 \\
\hline 2015 & 34 & \\
\hline
\end{tabular}

According to Table 1 students were relatively successful in completing the degree in the stipulated time. In 2012 the research project was introduced and only 2 students have completed the research project. In the third column only those 2 students graduated in 2014. This clearly shows the impact of the research project on the throughput rate of students and it underlines the fact that WSU Ibika Site is facing huge challenges in its quest to progress from a resource-based economy to a knowledge-based economy.

The same is true for the MEd students that I am supervising. Some of them have finished the course work as far back as 2010, but are still busy with the mini-dissertation. Apparently, the problem does not only exist at WSU Ibika Site but it is a general problem in the WSU Faculty of Education. In its first Faculty Board meeting in 2014 it was reported by the then School of Continuing Professional Teacher Development (CPTD) that there will be no new intake of MEd and DEd students for 2014, because of the many students that 'block' the system. This, in a time where higher institutions, such as Rhodes, Stellenbosch, and so forth had taken a conscious decision to increase the postgraduate intake and decrease their undergraduate student intake. It was only the timely intervention by the Deputy Vice-Chancellor Academic and Research that convinced the faculty to continue with the intake of these students.

\section{THEORETICAL FRAMEWORK}

In order to achieve the aim and objectives of the study, and to find answers to the research questions the researcher constructed a theoretical framework that would include research capacity and development. For the purpose of the current article, capacity development is 
viewed through the lens of social critical theory and development theory. Social critical theory recognises that although people can act consciously to change their social and economic circumstances, their ability to do so is constrained by various forms of social, cultural and political domination.

Wenger's (1998) in describing the social critical theory argues that human beings are social beings and this fact is central to capacity building and development. He argues that capacity building is based upon four components, namely 'learning as belonging, learning as becoming, learning as experience, and learning as doing' (Wenger 1998, 4). He explains that these components 'are deeply interconnected and mutually defining' and that is why he uses the concept 'communities of practice' (Wenger 1998, 5). He further explains that the concept 'communities of practice' includes, firstly, meaning making, which is a way of talking about people's (changing) abilities (individually and collectively) to experience their life and world as meaningful. Secondly, it includes 'practice', which is a way of talking about the shared historical and social resources, frameworks, and perspectives that can sustain mutual engagement in action. Wenger $(1998,8)$ insist that a process of apprenticeship has to take place. He understands practice to be a continuum, from no participation, to legitimate peripheral participation and, lastly, full participation.

Thirdly, it includes 'community', which is a way of talking about the social configuration in which people's enterprises are defined as worth pursuing and their participation is recognisable as competent. Lastly, the concept of 'community of practice' includes identity, which in a way of talking about how learning changes who people are, and creating personal histories of becoming in the context of their communities (Wenger 1998, 5).

Although social critical theory is concerned with addressing oppression and emancipation in society, it also concerns itself with institutional and conceptual transformations (Leonardo 2004). It is within this context that the article examines capacity development initiatives in research. By critically examining research capacity development, 'intellectual energy is spent on critiquing notions of power and privilege, whether in the form of cash or culture' (Leonardo 2004, 13). Critical social theory does not necessarily offer a blueprint solution to a given problem; however, crucial to this theory is that part of the solution can be found in how the problem is addressed.

Closely linked to locating research capacity development with a social context is the theory of how development takes place. Development theory focuses on an assortment of alternative theories on how societal change can best be realised (Adjibodou 2005). Modernisation theory, world system theory, dependency theory and state theory each contribute 
towards the process of development. Contemporary development strategies and policies include concepts such as poverty, dignity, participation, appropriate technology, sustainability and capacity building. For example, Schulze and Gouws (2008) talk about individual motivation of researchers and communities of practice as stimulants for research development.

The theoretical framework described was applied in the analysis, discussion and interpretation of data. The environment created by the mentors would enable students to progressively develop the discursive practices that will facilitate their participation in the communities of practice. This is in line with the view of Gee (2001) who conceives learning as a process of being mentored into the practices of discipline community.

\section{GOALS OF THE STUDY}

This study sought to investigate the challenges facing WSU Ibika Site to improve its throughput rate of postgraduate students. More importantly, to investigate the challenges post-graduate students are facing in completing their research project/dissertation on time.

\section{METHODS}

\section{Research design}

The phenomenological qualitative research approach (Henning, Van Rensburg and Smit 2004) was used for this research study. In this study specifically a qualitative orientation was deem well suited to conduct the research whose goals are to explore the challenges faced by postgraduate students to complete their research projects/mini-dissertations in the stipulated time. The phenomenological design endeavours to present the reality of participants from their own views (Henning et al. 2004)

\section{Participants and setting}

Fifteen BEd (Hons) and five MEd students from WSU Ibika Site were purposively selected to participate in the study. The sample size was 20. The following coding for participants were used: for the 15B Ed (Hons) students the coding was BEH1 to BEH15 and for the 5 MEd it was MED1 to MED5.

\section{Data collection}

Data on the challenges faced by these students in completing the research component of their respective programmes were collected using unstructured in-depth interviews supplemented 
with field notes. Field notes were collected on each interview describing the setting in which the interview took place, the people and activities. To ensure data trustworthiness participants were provided with feedback on the transcriptions of their individual responses to confirm whether the transcriptions were a true reflection of their views. Thus, participants had an opportunity to provide their opinion regarding the accuracy of the interpretation of the transcriptions.

\section{Procedure}

Informed consent was sought from the participants in the study. Ethical considerations such as honesty, trustworthiness, anonymity, and confidentiality were employed to ensure that the data provided would not be used against them, but would merely be used for the purpose of the research study.

\section{Data analysis}

Data were thematically analysed. Beginning with content analysis (Nieuwenhuis 2008) the researcher sought to extract themes and metaphors to organise and make sense of the data obtained. Responses were put into categories on the basis of the meaning they conveyed.

\section{RESULTS}

The themes emerged from the data analysis are indicated in Table 2.

Table 2: Challenges faced by B Ed (Hons) and M Ed students to complete their research projects/minidissertations in time

\begin{tabular}{|c|c|}
\hline Categories/Themes & Responses by participants \\
\hline $\begin{array}{l}\text { 1. Identification of the } \\
\text { problem statement }\end{array}$ & $\begin{array}{ll}\text { - } & \text { Problems with the suitability of the problem } \\
\text { - } & \text { Struggle to formulate the research problem } \\
\text { - } & \text { Sources where to find research topics or problems } \\
\text { - } & \text { Do not understand what the problem statement is } \\
\text { - } & \text { Posing a research problem as a statement is a challenge }\end{array}$ \\
\hline $\begin{array}{ll}\text { 2. } & \text { Complexity of } \\
\text { proposal writing }\end{array}$ & $\begin{array}{l}\text { - } \quad \text { This is the most problematic part of the research project } \\
\text { - } \quad \text { Focus and the function of the proposal is not well understood } \\
\text { - } \quad \text { Synthesising content into a proposal is difficult } \\
\text { - } \quad \text { Uncertain how the proposal need to be structured } \\
\text { - } \quad \text { Not sure about the types of research proposals } \\
\text { - } \quad \text { Components of the research proposal not consistent with all supervisors }\end{array}$ \\
\hline $\begin{array}{l}\text { 3. Academic writing } \\
\text { skills }\end{array}$ & $\begin{array}{ll}\text { - } & \text { Not clear what academic writing contains } \\
\text { - } & \text { Do not know whether to use simple language or academic language } \\
\text { - } & \text { Have the idea but cannot express it properly in the English language } \\
\text { - } & \text { Sometimes misunderstood because thinking in the mother tongue } \\
\text { - } & \text { Problem with logical exposition } \\
\text { - } & \text { Problems how/when to substantiate my argument } \\
\end{array}$ \\
\hline $\begin{array}{l}\text { 4. Research methods } \\
\text { not clearly understood }\end{array}$ & $\begin{array}{l}\text { - } \quad \text { Know the three methods but are not sure when/how/why to use it } \\
\text { - } \quad \text { Sometimes I misunderstood when to use qualitative or quantitative methods } \\
\text { Quantitative methods are very difficult especially when it comes to the analysis } \\
\text { of the data }\end{array}$ \\
\hline
\end{tabular}




\begin{tabular}{|c|c|}
\hline Categories/Themes & Responses by participants \\
\hline & $\begin{array}{l}\text { - } \quad \text { Not always sure which method to choose. } \\
\text { - Which factors must be taken into account in deciding on the method } \\
\text { - What influence does the particular purpose of the research project have on the } \\
\text { selection of the methods and techniques }\end{array}$ \\
\hline 5. Lack of resources & $\begin{array}{l}\text { - } \quad \text { Very few computers in a working environment } \\
\text { - } \quad \text { Not a proper functioning computer lab allocated to the Faculty of Education } \\
\text { - } \quad \text { Do not receive training in using the SPSS package } \\
\text { - } \quad \text { No research centre at Ibika } \\
\text { - } \quad \text { Very few dissertations/theses in the library to use as examples } \\
\end{array}$ \\
\hline $\begin{array}{ll}\text { 6. Student-supervisor } \\
\text { relationship }\end{array}$ & $\begin{array}{l}\text { - } \quad \text { Generally good relations exist } \\
\text { - } \quad \text { Most supervisors understand the problems students are struggling with } \\
\text { - } \quad \text { However, there are some that are very rude } \\
\text { - } \quad \text { They do not listen to the problems of the students } \\
\text { - } \quad \text { Always negative comments } \\
\text { - Sometimes I go home very despondent because of the over excessive use of } \\
\text { the red pen } \\
\text { - Some supervisors do not motivate and encourage students - it seems they do } \\
\quad \text { not want us to progress in live }\end{array}$ \\
\hline $\begin{array}{l}\text { 7. Delay with the } \\
\text { external assessment } \\
\text { process }\end{array}$ & $\begin{array}{l}\text { - From the date of submission for externalising the research project to the } \\
\text { eventual completion of the marks takes too long } \\
\text { - I waited more than } 6 \text { months for my final results (MEd student) } \\
\text { - } \quad \text { Supervisors are not eager to assist students with their work } \\
\text { - } \quad \text { Always a struggle to get supervisors }\end{array}$ \\
\hline
\end{tabular}

\section{DISCUSSION}

\section{Identification of the problem statement}

Most of the respondents indicated that the suitability of the problem; sources where to find research topics or problems; the struggle to formulate the research problem; and posing the research problem as a statement were challenges they experienced. The following excerpts expressed the view of the participants: 'I do not understand what the problem statement is' (BEH1). 'Although the lecturer explained the problem statement it is still vague to me' (BEH4). 'I find difficulty in obtaining the sources where I could find the problem for research' (MED5).

The above excerpts by the respondents clearly indicated the problems experiencing by students to pose a research problem. These views by the participants are in line with what Babbie and Mouton (2001) purports when they state 'The selection of a subject for research, and in particular the formulation of a title, often creates a problem for student researchers'. Daun and Strömqvist (2011) agree with this view when they argue that some students' problem statements are so broad that it would be probably take years to obtain valid information. This is why Le Grange $(2009,1118)$ believes that because of 'the vagueness of the general problem statement, any conclusion drawn would only be a general conclusion and would most probably be useless'.

It is the researcher's view that the research problem should be posed concisely, clearly and succinctly. It can be presented as a statement. A statement is a declaration or a formal 
account of facts according to Maree (2010). The main idea is to demarcate the problem clearly so that any person who reads the statement will be able to understand it without the aid of explanations, for example: 'Education in the management and policy leads to higher productivity of chief directors in the Eastern Cape Department of Education’.

\section{Complexity of proposal writing}

According to the analysed data most respondents regarded proposal writing as the most problematic part of the research study. They found that the focus and the function of the proposal is not well understood and synthesising content into a proposal is difficult. Furthermore, the uncertainty of how the proposal need to be structured; the types of research proposals; and the components of the research proposal are some of the difficulties indicated by the participants. These views are well supported by the following quotations: 'I struggle with the research proposal and find that I cannot move in my research' (BEH15). 'I sometimes feel to just to abandon my studies, because I am struggling now for almost a year to complete my research proposal' (MED3). 'The writing of a research proposal differs from lecturer to lecturer' (BEH9).

The research proposal is a comprehensive written plan of action compiled by the researcher (Creswell 2008). It clearly indicates how the researcher proposes to undertake a particular research project, often with a view to obtaining an advanced degree. In this regard McMillan and Schumacher (2006) suggest that the aim of the research proposal should be to convince a study leader, promoter or the reviewing committee of the proposal that the intended research project is indeed researchable. It is therefore important that students be provided with a template or guidelines of the components of the research proposal.

\section{Academic writing skills}

Most of the participants indicated that they struggle to express themselves in the English language because their home language is IsiXhosa. The following excerpts by some of the respondents clearly underline the above stated problem: 'I am thinking in the mother tongue and cannot put my thoughts in proper English' (BEH7); 'It is difficult to follow the explanation of the supervisor, especially if he explains in English' (MED3); 'All the lectures are in English, especially research Methodology, and I find it difficult to follow’ (BEH13).

Finkelstein $(2010,221)$ explains very succinctly that not all researchers are 'linguistic experts and it is not possible that within the boundaries of a research project to teach a researcher grammar and style'. It is precisely the view of the author of this article that due to the 
shortcomings expressed by the participants that the researcher should submit his/her report to an editor so that the manuscript can be edited for grammatical and technical correctness. I wish to iterate what I am telling my students that the cost involved in this type of service is small in comparison to the cost of a research report not being accepted because of grammatical or layout errors. However, Tight $(2007,241)$ cautioned that an editor cannot verify the facts or data, or improve the quality of the actual content of the report - that remains the sole responsibility of the researcher.

It is often suggested to start with the writing of the report as soon as possible. However, most of the participants indicated that they are not clear what to write because they do not know whether to write in academic writing or to use simple language. Others have indicated that they have the ideas what to write but they cannot express themselves properly; sometimes they are misunderstood because they are thinking in their mother tongue and not in English; they have a problem with logical exposition; and do not know when and how to substantiate their arguments. Botha $(2014,1981)$ agrees with the views expressed by the participants when she states: 'Many students are able to present their knowledge orally, but when it comes to writing their ideas are not elaborated upon - either because of the lack of language competency, or because they are unfamiliar with the conventions of academic discourse'.

Manzon (2011) provide a suitable solution for the problems and challenges stated by the participants when he states: 'Writing a research report is in itself an exercise in academic writing, i.e. the use of applicable, understandable terminology presented in clear, lucid, nonambiguous language with a view that the reader should have a clear understanding of what exactly the researcher refers to, i.e. that there should be no possibility of any misunderstanding whatsoever'.

The author wishes to align himself with the view express by Manzon, because the mere rewriting of the viewpoints and explanations of other writers or researchers, without endeavouring to interpret and/or integrate these into a new or adapted viewpoint or explanation, is not research - it is merely the transfer of knowledge from one place or format to another. The task of the true and dedicated researcher is to create 'new' knowledge and to present this knowledge as lucidly and concisely as possible.

\section{Research methods are not clearly understood}

One would not expect this sort of respond from BEd (Hons) or MEd students, but the majority of participants indicated that they are not sure which research method to use. The following quotations captured the views of the participants very well: 'I know the three methods but are 
not sure when/how/why to use it' (MED4); 'I am sometimes confuse what is quantitative and what is qualitative research methods' (BEH8); 'Thought the lecturer explained which factors to take into consideration to decide on a specific method I still find it very difficult' (BEH10).

This is one of the most basic requirement of any research project - the research approach/method to use. Most of the primary and secondary sources explain this very clearly. For example, Mouton (1983, 128) states as follows: 'In quantitative methodology, the researcher assigns numbers to observations. By counting and measuring "things” or “objects”, data is produced.' De Vos, Strydom, Fouche and Delport (2002, 79) describe qualitative methodology as follows: 'Qualitative methodology refers to research that produces descriptive data - generally the participant's own written or spoken words pertaining to his experience or perception. Usually no numbers or counts are assigned to these observations.'

There is another approach that can be used, namely the mixed methods. It is important that these concepts/approaches should be well understood even in the first year of university studies. In our scholarly teaching these concepts must be explained and students must be given the opportunity to use these methods and must understand why they are using a particular method.

\section{Lack of resources}

Most of the participants bemoaned the fact that resources at WSU Ibika Site are not up to standard. Their reasons are a lack of computers; no proper functioning computer lab in the Faculty of Education; a lack of a proper established research centre; very little training is taking place in the tools for analysis of data; and that the library holdings are inadequate for postgraduate students. Some of the quotations to substantiate these views are as follows: 'Most universities have the basic research tools to analyse data. My research study could have been finished by now, but I am struggling with the analysis of data' (MED2); 'We are expected to pay fees like all other universities in the country, but if it comes to resources we are falling short' (MED4); 'This university does not care about its students' (BEH7).

At an institution of Higher Education resources to be used are not negotiable. It is even more necessary when we speak of an institution with postgraduate students where most of the work they are doing is research related. These comments from the participants are a clear indication that WSU has a lot to do to increase the basic resources, for example, each research room must have Wi-Fi connections; fully functioning computers; training in SPSS and other quantitative and qualitative data analysis techniques. Thaver et al. $(2013,1136)$ is in agreement when he argues resources for research studies are important to enhance the expertise of students 
with respect to the student's knowledge of developments in the field of study. According to April, Loubsher, Ozbilgin and Al Ariss $(2013,1170)$ the primary intention of a research project is to excavate the nuances, critiques and anxieties that emerged in the field of gathering 'new knowledge' and for this reason adequate provision should be made for effective resources that students can use.

\section{Student-supervisor relationship}

The data indicated that generally a good relationship between student and supervisor exist. This view is substantiated by one participant who states that 'Most supervisors understand the problems students are struggling with' (BEH10). However, there are those participants who had strong views regarding the relationship between the supervisor and students. This is well summarise by the views of the following participants: 'Some supervisors are plain rude' (MED3); 'Supervisors force students to think the way they are thinking' (BEH14) and 'Supervisors always have negative comments; nothing positive that can motivate a person' (MED1).

It is my view that the attitude of the supervisor is of importance. A supervisor can make or break the spirit of a student. The main object should be to breed confidence - to be confidently humble, balanced by human understanding and empathy. Supervisors must understand the point of view of the student at the 'scene-setting phase' where the student and supervisor try to understand what the research is being envisaged, and what the purpose of the specific research is about. In this regard Henning et al. (2004) advice that the supervisor must at all cost avoid to argue with the student, because, according to the authors, it is a folly to argue. It tends to arouse antagonism and causes the untimely termination of the relationship between the supervisor and the supervisee.

The response of participants that question the quality of supervision at the institution is an ongoing concern. In this regard one respondent indicated that 'My supervisor is not sure what to do and then shout at me when I ask him for guidance' (BEH3). These attitudes and qualities of supervisors pose a significant barrier to timely completion of the BEd (Hons) or MEd degree. One can therefore make the inference that some of the reasons students are struggling to complete their degrees are because of inadequate, sporadic, or unskilled supervision. The template that is used by this university should be clearly explained to students and if necessary to lecturers as well. 


\section{Delay with the external moderation process}

Most of the respondents had a problem with the delay in finalising their work. Some indicated that they submitted their work on time but the delay is with the external examiner. At this university both the research projects for BEd (Hons) and mini-dissertations and dissertations by MEd students are submitted for external assessment. For the BEd (Hons) project one (1) external examiner is used and for the M Ed mini-dissertation and dissertations a minimum of two (2) external examiners are used. One of the participants indicated that: 'I waited more than 6 months for my final results' (MED4). This delay will then have a ripple effect, because the students cannot graduate on time and had to wait for the next graduation. The result is that they have to postpone further studies, because they cannot register for the next degree. This may diminish their feelings of achievement to that of self-doubt - self-doubt about able to compete with those who understand the social and cultural capital of the university domain. Some of the respondents indicated that the delay was caused by the examination section of the institution. However, they also argue that if supervisors were more efficient, effective and experienced then this kind of delay could be minimise.

\section{CONCLUSION AND RECOMMENDATIONS}

From the findings it can be concluded that for WSU to improve its throughput rate of postgraduate students the research methodology must be strengthened in the undergraduate level; academic writing skills need to be improved; resources should be improved; the relationship between student and supervisor need to be addressed; and more supervisors need to be appointed.

The Minister of Higher Education and Training is on record highlighting the worrying fact that the South Africa's share of global research output has been declining over the last decade. This research study had revealed the challenges experienced by WSU in its throughput rate of postgraduate students. It becomes an increasingly worrying aspect for the institution to play its part in the economic development of the region and the country if the challenges mentioned in this article are not addressed.

In conclusion the author wishes to suggest some recommendations that might assist to address the challenges experienced by WSU in its throughput rate of postgraduate students:

- $\quad$ Employ the required number of adequately qualified staff to introduce research related modules from the first year of study to ensure that the students gain experience in research early in their academic programmes at the university. By doing so the university would 
strengthen its undergraduate level which eventually would lead to the development of a strong cohort of postgraduate students.

- The development of scholarly writing skills of students by changing from 'multistructural' to a 'relational' form of writing. The latter is no longer a listing of ideas and facts, but an attempt to make sense of the ideas 'in the light of their contribution to the topic as a whole’ (Salem, Dison, Gennrich and Nkambule 2013, 1085). More specifically, a relational form of writing focusses on the inter-relationship between ideas, analyses of ideas in relation to other ideas and orders parts of texts by imposing a structure and a principled gaze. The method of coaching could also be introduced in the first year of study especially in writing assignments. The content of the assignment becomes less important than the development of scholarly writing. To this end coaching in writing becomes particularly significant and the assignment becomes a teaching tool.

- As far as the language problem is concerned that was highlighted as a challenge by the participants, the author agrees that not all researchers are linguistic experts and it is not possible, within the boundaries of a research project or dissertation or thesis to teach a researcher grammar and style. It is precisely due to this shortcoming that the researcher should submit his or her work to an editor so that the manuscript can be edited for grammatical and technical correctness. The cost involved in this type of service is small in comparison to the cost of a research report not being accepted because of grammatical or layout errors.

- WSU is currently engaged in a restructuring process from a unitary institution to a multicampus one. The restructuring process severely affected the pace of research development and the research output at WSU as the university focuses on wrestling with the implementation of the restructuring plans, the research and development plans, the numerous policy changes and the new research funding formula that was introduced. WSU at Ibika clearly does not have the resources as far as financial and human capital are concern to deliver on the huge demand to increase its postgraduate throughput rate. Inequalities in research infrastructure still largely reflect the distortions of the past and the cohort of young and new researchers is being developed at a relatively slow pace. To correct this it not only includes capacity building at an individual level with the supervisor as a researcher focus, but also organisational development through platform development and the involvement of HoDs. The faculty management must play a leading role in this regard and should not only rely on the faculty budget but should also start to write proposals for external funding. 


\section{REFERENCES}

Adjibodou, M. 2005. Understanding development theory in the context of social and community change, 1-32. September.

April, K., J. Loubsher, M. Ozbilgin and A. Al Ariss. 2013. Managing diversity in higher education: Understanding and tackling ethnic stratification in social comfort. South African Journal of Higher Education 27(5): 1164-1180.

Babbie, E. and J. Mouton. 2001. The practice of social research. Cape Town: Oxford University Press.

Botha, E. M. 2014. What were they all about? Two questions that provoked different reactions and feelings. South African Journal of Higher Education 28(6): 1972-1985.

Campbell, R. 2003. Preparing the next generation of scientists: The social process of managing students. Social Studies of Science 33(6): 897-927.

Creswell, J. W. 2008. Research design: Qualitative, quantitative and mixed methods approaches. London: Sage Publishers.

Daun, H. and G. Strömqvist. 2011. Education and the development in the context of globalization. New York: Nova Science.

Department of Education. 2007. The Higher Education Qualifications Framework. Higher Education Act, No. 101 of 1997. Government Gazette. 5 October.

Department of Higher Education and Training. 2012. Green Paper for post-school education and training. Pretoria: Department of Higher Education and training. www.info.gov.za/view/ downloadFileAction

Department of Science and Technology. 2013. Address by the Minister of Science and Technology, Derek Hanekom, at the National Science Deans Forum, 5 April, Intercontinental Hotel, OR Tambo International Airport, Johannesburg, South Africa. http://www.info.gov.za/speech/ DynamicAction?pageid=461andsid=35533andtid=103780 (accessed 25 March 2016).

De Vos, A. S., H. Strydom, C. B. Fouche and C. S. L. Delport. 2002. Research at grass roots for social sciences and human service professions. Pretoria: Van Schaik.

DHET, see Department of Higher Education and Training.

DoE, see Department of Education.

DST, see Department of Science and Technology.

Finkelstein, M. 2010. The balance between teaching and research in the work-life of American academics. In The changing academic profession in international and quantitative perspectives: A focus on teaching and research activities, 213-233. Hiroshima: research Institute for Higher Education, Hiroshima University.

Gee, J. P. 2001. Identity as an analytical lens for research in education. Review of Research in Education 25(2000-2001): 95-125.

Henning, E., W. van Rensburg and B. Smit. 2004. Finding your way in qualitative research. Pretoria: Van Schaik.

HESA, see Higher Education of South Africa.

Higher Education of South Africa. 2013. HESA Annual Report. http://www.hesa.org.za (accessed 24 March 2016).

Le Grange, L. 2009. A survey of educational research in the second decade of South Africa's democracy: A focus on higher education. South African Journal of Higher Education 23(6): 1115-1125.

Leonardo, Z. 2004. Critical social theory and transformative knowledge: The function of criticism in quality education. Educational Researcher 33(6): 11-18.

Manzon, M. 2011. Comparative education: The construction of a field. Springer: Comparative Education Research Centre, the University of Hong Kong. 
Maree, K. 2010. First steps in research. Pretoria: Van Schaik.

McMillan, J. H. and S. Schumacher. 2006. Research in education: Evidence-based inquiry. Boston: Pearson Education Inc.

Mouton, J. 1983. Kwantitatiewe en kwalitatiewe metodologie in die geesteswetenskappe. South African Journal of Sociology 14(4): 125-135.

National Development Plan. 2013. NDP 2030. http://www.gov.za/issues/national_development _plan_2030 (accessed 24 March 2016).

NDP, see National Development Plan.

Niewenhuis, J. 2008. Analysing qualitative data. In First steps in research, ed. K. Maree. Pretoria: Van Schaik.

Phakiti, A. 2008. Predicting NESB international postgraduate students' academic achievement: A structural equation modelling approach. International Journal of Applied Educational Studies 3(1): 18-38.

Quinn, L. 2012. Understanding resistance: An analysis of discourses in academic staff development. Studies in Higher Education 37(1): 69-83.

Salem, Y., L. Dison, T. Gennrich and T. Nkambule. 2013. 'I don't understand everything here ... I'm scared’. South African Journal of Higher Education 27(5): 1081-1098.

Schulze, S. and E. Gouws. 2008. Proven researcher's perceptions of influences on academics' research output. A case study. Acta Academica 40(2): 129-152.

Thaver, B., L. Holtman and C. Julie. 2013. Inducting BEd Hons students into a research culture and the world of research. South African Journal of Higher Education 27(5): 1135-1148.

Tight, M. 2007. Bridging the divide: A comparative analysis of articles in higher education journals published inside and outside North America. Higher Education Review 53(2): 235-253.

Wenger, E. 1998. Communities of practice. Learning, meaning and identity. New York: Cambridge University Press. 